\title{
Ante el peligro
}

qué hará México? iY qué ha de hacer México sino ca. pitular! Esta primera batalla tenemos que perderla los pueblos de nuestra habla. Lo importante es que aprendamos de la derrota misma el secreto de la victoria anglosajona: Fas est et $a b$ hosfe doceri, decian los latinos. Del enemigo, el consejo. traduce el pueblo nuestro. Hay quien cree que la batalla de América está perdida para todos los pueblos latinos. Hay quien opina que sólo se perderá hasta el Canal de Panamá. Pero yo creo que si aprendemos la lección, no se perderá nada, ni Puerlo Rico mismo. Ya sé que los Eslados Unidos son un árbol gigantesco que va extendiendo sus raices por donde encuentra tierra fresca. Pero si somos hábiles esas raices se volverán a la tierra norteamericana, a Dios gracias lo bastante amplia y rica para proveerlas de cuanta savia necesiten.

Con lo que quiere México, todo español, todo hombre de buena volunlad tiene que estar de acuerdo. México quiere que no sirvan sus propias riquezas naturales para someter el pais al extranjero. Pero el método con que México ha querido realizar su voluntad es demasiado sencillo para que se pueda confiar en su eficacia. $\mathrm{Ha}$ promulgado una Constitución que eslablece la nacionalización de la riqueza. Más de cincuenta años nos ha costado a los españoles nacionalizar, en el sentido mexicano, nuestros ferrocarriles. Pesela a peseta hemos rescalado en medio siglo la mayor parte del capital ferroviario. ¿Habriamos necesitado tanto tiempo de haber podido arreglar este negocio con un articulito de la Constitución? El Gobierno de Wáshington ha declarado ya que no lo acepta. Los ciudadanos norleamericanos, que 
poseen en México explotaciones petroleras contarán con la prolección de su Gobierno, en su resistencia a la ley mexicana, que los obliga a enajenar sus propiedades o a adoplar la nacionalidad del pais donde sus bienes radican.

México es la fronlera y el símbolo de toda la América española. ¿Podrá ésla defender su independencia económica con leyes que nacionalicen sus riquezas? Quizás la pueda defender contra España, quizás contra Europa. porque para eso la prolege la doctrina de Monroe, pero no contra el pais de Monroe, a menos que no lo consienta el Gobierno de Wáshington, y Wáshington, por lo visto, no quiere que se expropie a los capitalistas norleamericanos, sin la indemnización a que tienen derecho. Rusia ha podido expropiar a los acreedores e industriales extranjeros, sin indemnizarlos, gracias a que es militarmente inconquistable. Tampico no es tan inaccesible como Moscou. Pero lampoco Rusia ha realizado impunemente sla expropiación de los expropiadores. Al cabo de una década de hambre ha caido ya en la cuenta, en el último Congreso comunista, de que la alternativa al capilalismo no es el socialismo sino la miseria.

El ogro del tiempo no cesa de destruir capilal. Las casas se caen, las máquinas se gastan, las tierras se inundan, los hierros se oxidan, los caminos se agrielan. La mera conservación de las riquezas existentes, sin contar con la necesidad de acumular recursos para preparar el trabajo de las generaciones venideras, exige una incesanile creación de capilal. El Eslado no sirve para ello. El Estado no sirve sino para consumir los recursos que el ahorro particular concentra. Y mientras el Estado no muestre para hacer dinero la misma capacidad que revela para gaslarlo. ¿no es cándido imaginarse que pueda sustiluir a la propiedad privada en la función de crear los capitales necesarios? El socialismo no es alternativa al capitalismo. O se tiene dinero o no se tiene. Esta es la verdadera alternativa. Y la carencia de dinero es la miseria.

Todos los pueblos hispanoamericanos están fallos de capital. Todos han acudido en su busca a las bancas norteamericanas. Todos deben dinero a los Estados Unidos. Ello no debiera ser 
asi. No necesitaba ser asi. En todos los pueblos hispanoamericanos hay grandes riquezas, que han podido explotarse, en buena parte, con capitales hispanoamericanos, si no se hubieran consumido inútilmente estos capilales en París. En su libro El nacionalismo continental dice don Joaquin Edwards Bello que los negocios chilenos no prosperan tanto como los norteamericanos porque Chile es pais pequeño. mientras los Eslados Unidos lo son grande. El ideal continental del señor Edwards es también el mio. Lo único que quisiera es que lo agrandase hasta incluir al Porlugal y a España. Pero el famaño de la nación no va a reformar por si solo el carácter de los hispanoamericanos. Los holandeses no han necesitado constituir un gran Imperio para ser una de las grandes polencias financieras del mundo.

La defensa eficaz de los pueblos hispanoamericanos consiste en constituir capital propio. Esta es la verdadera alternativa al capilalismo norleamericano. No se improvisa. Requiere lenacidad, constancia, privaciones, ahorro, inteligencia, austeridad. Probablemente necesita, como condición previa, una reforma del carácler. Si quiere el señor Edwards que le defina en qué consiste la diferencia fundamental que existe entre un anglosajón y un hispanoamericano o un español. le diré que para los mejores de nosotros el dinero no pasa de ser nunca una comodidad, mientras que para los mejores de los anglosajones es también un deber. Desde luego que el inglés o el norlcamericano no es tampoco remiso para apreciar los placeres que con el dinero puede procurarse. Pero esta es la añadidura. Lo característico no es eso, sin embargo, sino que mira el dinero como sacramento, como signo de gracia, por creer que el favor divino generalmente se conoce en la prosperidad del que lo recibe.

Esta teologia no necesita interesarnos. Una cosa hay en clla de verdadero. El dinero es poder, y el poder no es meramente conveniencia, sino deber. Pero si ello es exacto, no ha menester el señor Edwards de otra explicación para comprender la superioridad de los anglosajones. Nuestra conducta no es sino 
el resultado de nuestros juicios de valoración. Si creemos que la vida mejor es la contemplativa, daremos a los conventos nuestras almas mejores. Si pensamos que no hay nada mejor que imponer violentamente nuestra voluntad a los demás. seremos revolucionarios. Si juzgamos que la idea del deber, es una barrera que no necesita detener más que a los tontos y que el dinero es el supremo bien, trataremos de enriquecernos de cualquier manera, aunque sea empobreciendo a los demás. Pero si entendemos que el deber y el dinero se unen en alguna forma, más o menos clara. de tal suerte que el dinero que se hace malamente no aprovecha, y que tampoco se cumple el deber cuando se descuida la obligación de enriquecerse. a menos que la impida un deber superior, como la ciencia, el arte o el servicio social, entonces procuraremos unir en nuestro ideal la economia y la moral, y si este ideal se ajusta a la naturaleza de las cosas nos conducirá al triunfo. de la misma manera que un ideal equivocado nos llevará al desastre.

La defensa de la América española está en crear capital propio: pero para ello ha de cambiar su tabla de valores.

RAMIRO DE MAEZTU.

(EI Sol, Madrid). 